\title{
Habitat structure and their influence in lizard's presence
}

\section{Beatriz Nunes Cosendey ${ }^{1,3}$; Carlos Frederico Duarte da Rocha ${ }^{1,4}$ \& Vanderlaine Amaral de Menezes ${ }^{2,5}$}

\author{
1 Universidade do Estado do Rio de Janeiro (UERJ), Instituto de Biologia Roberto Alcantara Gomes (IBRAG), Departamento de Ecologia (DECOL), \\ Laboratório de Ecologia de Vertebrados. Rio de Janeiro, RJ, Brasil. \\ ${ }^{2}$ Fundação Centro Universitário Estadual da Zona Oeste (UEZO), Unidade de Biologia (UBI0). Rio de Janeiro, RJ, Brasil. \\ 3 ORCID: http://orcid.org/0000-0002-9049-4328. E-mail: bcosendey@gmail.com \\ ${ }^{4}$ ORCID: http://orcid.org/0000-0003-3000-1242. E-mail: cdfrocha@gmail.com \\ ${ }^{5}$ ORCID: http://orcid.org/0000-0002-6797-5975. E-mail: va.menezes@gmail.com
}

\begin{abstract}
Many species are declining due to environmental and physical changes in their habitats. Such disturbs alter the availability of micro-habitats and influences the presence of lizards, being even worse for threatened and endemic species. Glaucomastix littoralis is a teiid species restricted to four restingas areas of Brazil. The understanding about the use and preferences of micro-habitats by the species and the consequents effects of substrate loss is important to prevent local extinctions. This study took place in restingas of Maricá, Jurubatiba and Grussaí, in Rio de Janeiro State. We sampled the vegetation of all areas, to access differences between the physical structures, and recorded the individuals sighted and the micro-habitat they were in, to investigate the relation of individuals and habitat structure. We calculated the frequency utilization of each micro-habitat and made a presence estimation of individuals (occupancy and detection probability) to assess which structural parameters of vegetation guide the settlement of the studied populations. Our data showed structural vegetation particularities among the areas and a trend concerning the use of micro-habitat by Glaucomastix littoralis, with a general preference for leaf litter inside bushes, guriri and bare sand and a low utilization of cactus and herbaceous. We also found positives (bare sand and cactus) and negatives (bushes) influences of micro-habitats in relation to the occupation of the areas by the individuals. Since vegetation is fundamental to lizards, due to their use as a refuge, site for thermoregulation and feeding, the understanding about the effects habitat degradation/fragmentation can cause is essential to create appropriate management plans and develop public policies to conserve the species.
\end{abstract}

Key-Words. Conservation; Habitat structure; Micro-habitat; Sand dune coastal areas; Threatened species.

\section{INTRODUCTION}

Spatial heterogeneity is known to be an important environmental variable for several organisms. The mosaic of micro-habitat generated by vegetation structure provides distinct physical conditions with different intensities of light, temperature and humidity, influencing local diversity and affecting distribution pattern of species (Oliveira et al., 1994; Cerqueira et al., 2003; Radder et al., 2005; Dias \& Rocha, 2014). The variety of microclimates generated by the micro-habitats encompasses a range of environmental conditions that can be needed, or avoided, by organisms depending on their activities and hours of the day (Sinervo et al., 2010). The physical characteristics of the habitat, such as open or closed vegetation, wind, shade or direct exposure to sunlight influence the maintenance of local individuals' body temperature, mainly the ectothermic ones, consequently affecting their choice of habitat (Menezes et al., 2011; Maia-Carneiro et al., 2012).
Restinga is a sand dune habitat of Mata Atlântica environment that occurs along the Brazilian coast $(5,000 \mathrm{~km})$ and is under extensive degradation over the last 500 years (Rocha et al., 2004, 2005). The anthropogenic fragmentation and habitat loss of this ecosystem diminish the quality of natural micro-habitats and isolate populations, making migrations difficult due to the inability of local individuals to transpose the matrix (e.g., large roads, houses), which can cause population breaks and loss of gene flow (Ariani et al., 2013). Lizards' species that are habitat-specific of restinga' ecosystems tend to be the most affected by anthropogenic disturbances (Silva \& Araújo, 2008). Physical changes in the environment, fragmentation of the habitat and changes in local climate influence population dynamics, causing the decline of many lizard's species and populations nowadays (Rocha et al., 2009; Clobert et al., 2009; Sinervo et al., 2010; Cosendey et al., 2016).

Glaucomastix littoralis, a teiidae lizards' species endemic to restinga ecosystems, is known to 
occur in only four areas of Rio de Janeiro state (Maricá, Jurubatiba, Grussai and Marambaia - Menezes \& Rocha, 2013) and is classified as "endangered" in the Brazilian Endangered Fauna List (MMA, 2014). Its restricted distribution (to four restingas areas of Rio de Janeiro) is even more impaired due to habitat loss in the Brazilian coastal areas (Rocha et al., 2007). Once the structure of the habitat is fundamental to generate opportunities for lizards, which affects their population densities and the composition of the community they belong (e.g., Kohn \& Leviten, 1976; Rocha \& Bergallo, 1997; Dias \& Rocha, 2014), the understanding of how individuals use the vegetation and the effects substrate loss could cause is of major relevance to prevent local extinctions.

In the present study we tried to elucidate: (i) The key micro-habitats used by G. littoralis in the restingas, (ii) If there are structural differences in the studied phytophysiognomy among three areas where G. littoralis occurs, (iii) If the structure of the micro-habitat influences positively or negatively the occupation of the areas by this lizards' species.

\section{METHODS}

\section{Study Area}

We carried out our fieldwork in three restinga areas of Rio de Janeiro state: Grussaí, Jurubatiba and Barra de Maricá. The lagunar complex Grussaí/lquipari $\left(21^{\circ} 44^{\prime} \mathrm{S}\right.$, $\left.41^{\circ} 02^{\prime} \mathrm{W}\right)$, located in São João da Barra, at the north part of the state, is about $7.28 \mathrm{~km}$ long. The mean annual temperature in the area is about $23^{\circ} \mathrm{C}$ (Rocha et al., 2008) and total annual rainfall ranges from $800 \mathrm{~mm}$ to $1,200 \mathrm{~mm}$, with a rainy season occurring between November and March (Cesário \& Gaglianone, 2008). A Private Natural Heritage Reserve (RPPN - Reserva Particular do Patrimônio Natural) was created in 2011, after the beginning of the construction of Porto do Açu (a harbor in the region) in 2007. The restinga of Jurubatiba $\left(22^{\circ} 17^{\prime} \mathrm{S}, 41^{\circ} 41^{\prime} \mathrm{W}\right)$, located in the municipality of Macaé, also in the north, is one of the largest restinga areas of the state, with $44 \mathrm{~km}$ length (Rocha et al., 2007). Jurubatiba's mean annual temperature is $22.6^{\circ} \mathrm{C}$ (Menezes et al., 2006; Montezuma \& Araujo, 2007) and mean annual rainfall is $1,300 \mathrm{~mm}$, with a rainy season occurring between October and April (Montezuma \& Araujo, 2007). It also belongs to a National Park area (PNRJ - Parque Nacional da Restinga de Jurubatiba) created in 1998, and has an area about $148.6 \mathrm{~km}^{2}$ (Montezuma \& Araujo, 2007). The restinga of Barra de Maricá $\left(22^{\circ} 57^{\prime} \mathrm{S}, 42^{\circ} 52^{\prime} \mathrm{W}\right)$, located in Maricá municipality, is nearly $6.2 \mathrm{~km}$ long. Mean annual temperature in the area ranges from $22^{\circ} \mathrm{C}$ to $24^{\circ} \mathrm{C}$ and total annual rainfall from 1,000 to 1,350 $\mathrm{mm}$ (Nimer 1972; Franco et al., 1984), with about $70 \%$ of precipitation occurring from November to April (Pereira et al., 2001). Restinga of Maricá is a protected area (APA - Área de Proteção Ambiental) created in April, 1984 by the State Decree № 7.230 (Pereira et al., 2001).

\section{Sampling Design}

To feature the structure of vegetation, micro-habitat use and count of lizards, we sampled the three studied restingas between December 2013 and March 2014 (summer season). In each area we established 20 straight lines transects of $50 \mathrm{~m}$ parallel to the beach line, totaling 1,000 $\mathrm{m}$ of sampling. We demarked transects with the aid of a measuring tape and a directional compass and registered the geographic coordinates of the beginning and end of each one with a GPS. We distance each transect $50 \mathrm{~m}$ apart from each other. We considered this was a safety margin to avoid pseudoreplication (Hatano et al., 2001) and a feasible distance to record individuals before they could move to the next transect, although there are no studies regarding Glaucomastix littoralis home range yet. If an individual lizard ran toward to the next line, we disregard one of the counting. We made all the transections on the phytophysiognomy "Open NonFlooded shrubby" (Decree 41612-RJ, 2008) since it is the main occurrence area of $G$. littoralis (Teixeira-Filho et al., 1995; Rocha et al., 2001).

\section{Data Sampling}

We feature the micro-habitats available in all four restinga' habitat studied using the 20 transects lines of $50 \mathrm{~m}$ described in Sampling Design. Along these transects, we measured the length (in $\mathrm{cm}$ ) of the ground covered by bare sand, leaf litter and different types of vegetation (cactus, herbaceous, trees, bushes, grass, bromeliad and guriri seashore palm - Allagoptera sp.). We also measure the height of these different types of vegetation and the depth, in the case of leaf litter, and estimated the mean height/depth of each category. We considered both green (alive) and dry (dead or on track of) plants intercepted by the transect line on the ground. We considered as (i) herbaceous: small and/or young plants with non-woody stem; (ii) bushes: arboreal-shrub components of less than $1.80 \mathrm{~m}$; and (iii) trees: arboreal components of above $1.80 \mathrm{~m}$. In case of a cluster of different overlapping vegetation structures, we measured each one separately.

At these same 20 transects lines, an observer registered the number of individuals $G$. littoralis sighted and the micro-habitat they were in, in order to infer if there were preferences regarding the use of micro-habitats by lizards among the restingas. Two observers covered different transects at a time, four times a day, totalizing 40 minutes of observation per transect (four visits of 10 minutes). All observations were done during the activity period known for the species (08h50-15h00 - Hatano et al., 2001), in different time-intervals throughout the day, being two visits in the morning and two in the afternoon. The observers covered different transects concomitantly, in order to balance the observations of transects in all time intervals. The frequency of use of each micro-habitat by G. littoralis was estimated for each restinga habitat. 


\section{Data Analysis}

To estimate the percentage cover of the structural habitat, we divided the length of each structure of vegetation (green and dry), leaf litter and bare sand by the total sampled area in each restinga $(1 \mathrm{~km})$. To obtain a characterization of the vegetation structure of the different restinga areas, we input the measured habitat variables from all areas in an environmental matrix and then conducted a gradient of Principal Component Analysis (PCA). We used a correlation matrix for the PCA due to the discrepancy among the variables values (Mingoti, 2013). To determine how many axes should be used, we applied the Broken-stick criteria of selection (Jackson, 1993). The physical structures of the restingas were visually compared with the resulting biplot. We tested statistical differences between the physical structures testing the average scores of PCA axes with one-way ANOVA.

We evaluated the relationship between the number of individuals sighted in each transect and the gradient of variation in vegetation structure revealed by the PCA matrix cited before. To do so, we fitted a Generalized Linear Model (GLM) with each of the first two axes of PCA and the visit with the highest number of lizards' encounter rate (among the four done) for all of the 60 transects (20 in each restinga). We used the average height $(\mathrm{cm})$ and total length $(\mathrm{cm})$ of each category of vegetation transects. Statistical analysis was carried out in the program PC-ORD (McCune \& Mefford, 1999) and RStudio (RStudio Team, 2012), whereas the graphics were made in the software Microsoft EXCEL 2010 and ORIGIN 6.0 (Microcal Software, Northampton, MA). Data were previously tested by the Shapiro-Wilk test and normalized when necessary.

We also calculated the frequency of use of the micro-habitats by the lizards (percentage of individuals saw in each vegetation structure) and evaluated if there were differences in the choice of micro-habitat among the three areas with a Kolmogorov - Smirnov test for two independent samples. Thereafter, we performed different models to evaluate the relative importance of micro-habitats in habitat selection through Akaike weights criteria (Arnold, 2010). For that, we tested vegetation and sighting data (time $-1^{\text {st }}, 2^{\text {nd }}, 3^{\text {rd }}$ or $4^{\text {th }}$ period of sampling) in the software PRESENCE (Hines, 2006) to assess which parameters of vegetation structure influenced the local presence of populations studied. This analysis took into consideration the detection probability of each micro-habitat, calculating separately the probability of occupancy by the individuals and the effect of vegetation structure on lizard encounter rate. The analysis used in this software was the "single season": since sightings were conducted over a short period of time (about one week for each restinga), the population can be assumed to be closed (Anton et al., 2013). The variables selected to be tested in PRESENCE were based on the exploratory analysis of PCA that revealed which vegetation characteristics (length, height or depth, of the different structures measured) were more influential for each restinga. After comparing some models, we accepted those ones with a difference between the AIC (Akaike Information Criterion) and the AIC of the best model minor than two ( $\triangle \mathrm{AIC}<2.0)$, once it is considered to be more parsimonious. To ensure it was a valid selection (Arnold, 2010), we compared the models between each other to verify if there was no significant difference between them $(p>0.05)$ (MacKenzie, 2012). The calculation of $p$-value was made according to the $x^{2}$ distribution table, from the difference between the values of -2 log like and the number of parameters, corresponding to the values of $x^{2}$ and degrees of freedom, respectively (MacKenzie, 2012). We then analyzed for possible influences (direct or indirect) of the structural parameters of the habitat, selected by the best models, had in G. littoralis occupancy and the consequent damage the lack of certain habitat structure could cause.

\section{RESULTS}

\section{Vegetation Structure}

All restingas studied showed consistent differences in their vegetation structure (see appendix for information about the structure of the restingas). All types of vegetation pooled together represented an overall percentage cover of $42.8 \%$ in Maricá, $37.1 \%$ in Jurubatiba and $30.3 \%$ in Grussaí. The percentage of ground covered by leaf litter (both in portions of habitat with or without vegetation) was of $9.3 \%$ in Maricá, $18.4 \%$ in Jurubatiba and $29.9 \%$ in Grussaí, whereas portions of ground having bare sand was $47.8 \%$ in Maricá, $44.5 \%$ in Jurubatiba and 39.7\% in Grussaí.

In Maricá, the second structure after bare sand with the higher ground cover percentage was bush (19.8\%), followed by bromeliads (15.5\%). Maricá was the restinga with the highest proportion of bromeliads and the lowest occurrence of guriri $(0.5 \%)$ in relation to the others restinga areas studied. In contrast, restinga of Jurubatiba had the highest percentage of ground covered by guriri (14.9\%) and no record of grass species. In Grussaí, the proportion of bare sand $(39.8 \%)$ and bush (34.4\%) were similar. This was the restinga with the greatest percentage of ground covered by cactus (4.2\%) and grass species (3.3\%), and the lowest percentage of ground covered by bromeliads (5.5\%) (see appendix for information about the structure of the restingas).

The most important differences were captured by the first six axes from the Principal Component Analysis. The ANOVA results showed statistical differences in terms of vegetation structure among the three areas for axis 1 , 2 and 3, with the first two axes explaining, together, $36.29 \%$ of variation (Table 1).

Height of trees was the variable that most positively influenced the first axis and guriri the one which most negatively influenced it. For the second axis, the main variables influencing it were length of guriri (positive) and length of bushes (negative); and for the third axis, height of bromeliad (positive) and length of sand (negative - Table 2). The biplot showed transects of each rest- 
Table 1. PCA axes of vegetation structures with eigenvalue $>1$ and their percentage of variance, cumulative percentage of variance and Broken-Stick Eingenvalue. The last two lines show the ANOVA results and the statistical differences $(p)$ in terms of vegetation structure among the three areas. Each axis had $\mathrm{N}=60$. Data from restingas of Maricá, Jurubatiba and Grussaí in southeast coast of Brazil.

\begin{tabular}{lcccccc}
\hline & $\mathbf{P C 1}$ & $\mathbf{P C 2}$ & $\mathbf{P C 3}$ & $\mathbf{P C 4}$ & $\mathbf{P C 5}$ & $\mathbf{P C 6}$ \\
\hline Eigenvalue & 4.271 & 2.986 & 1.844 & 1.554 & 1.214 & 1.164 \\
\% of variance & 21.357 & 14.929 & 9.218 & 7.769 & 6.069 & 5.822 \\
Cum. \% of variance & 21.357 & 36.286 & 45.504 & 53.273 & 59.342 & 65.164 \\
Broken-Stick & 3.598 & 2.598 & 2.098 & 1.764 & 1.514 & 1.314 \\
ANOVA F & 43.28 & 33.90 & 3.49 & 1.3 & 0.43 & 0.53 \\
$\mathrm{p}$ & $<0.01$ & $<0.01$ & $<0.05$ & 0.28 & 0.44 & 0.59 \\
\hline
\end{tabular}

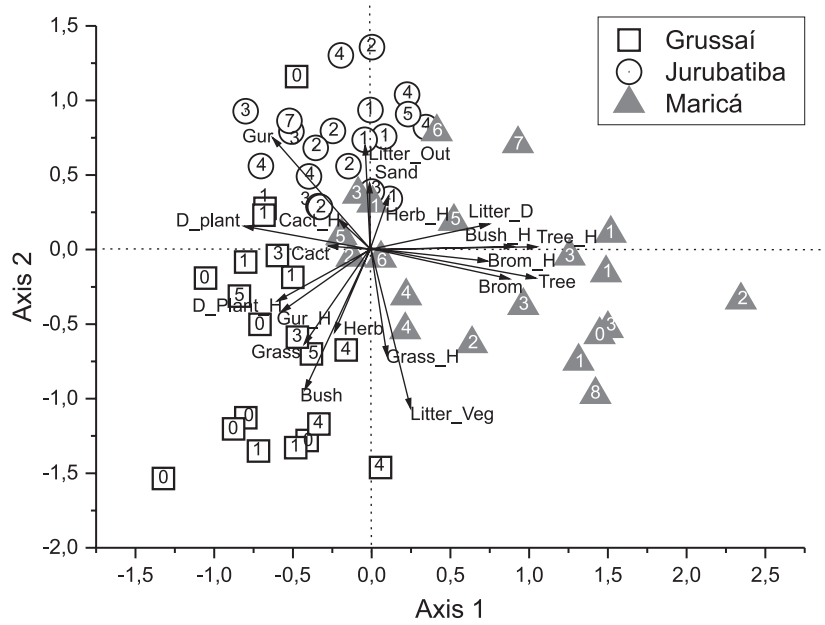

Figure 1. PCA of the vegetation structure of the three restingas; percentage of explanation of axis $1=21.36 \%$ and axis $2=14.93 \%$. Litter_Out $=$ extension of leaf litter outside bush (on bare sand); Litter_Veg = extension of leaf litter inside bushes or under some vegetation; Litter_D = average depth of leaf litter; Sand = extension of bare sand; Bush = extension of bushes; Bush_H = average height of bushes; Tree = extension of trees; Tree_H = average height of trees; Brom = extension of bromeliads; Brom_H = average height of bromeliads; Grass = extension of grass; Grass_H = average height of grass; Herb = extension of herbaceous; Herb_H = average height of herbaceous; Gur = extension of guriri; Gur_H = average height of guriri; D_Plant = extension of dried plants; D_Plant_H = average height of dried plants; Cactus = extension of cactus; Cactus_H = average height of cactus. Numbers inside the symbols correspond to the amount of individuals Glaucomastix littoralis sighted in each transect.

inga clustered apart from each other, especially Grussaí that stood out among them, with only one transect similar to Jurubatiba in terms of vegetation structure (Fig. 1). Axis 1, the principal component' axis (PC) that retained the largest variation in vegetation structure $(21.3 \%)$ was mainly represented by a gradient of height and length of dried plants, length of bushes (that were important to distinguish Grussaí from the other areas), extent and height of bromeliads and trees, height of bushes and depth of leaf litter (that distinguished Maricá transects from those of the other areas - Fig. 1, Table 2). Axis 2, that retained $14.9 \%$ of variance was represented by a gradient of length of bushes, herbaceous and grass species (that were important for Grussai) and height of herbaceous, length of bare sand, leaf litter outside vegetation
Table 2. Scores of each variable for the PCA axis with $p<0.05$

\begin{tabular}{lccc}
\hline \multicolumn{1}{c}{ Variable } & PC1 & PC2 & PC3 \\
\hline Bromeliad (lenght) & 0.88577 & -0.20131 & 0.31206 \\
Herbaceous (lenght) & -0.23574 & -0.56713 & -0.40403 \\
Leaf litter with vegetation & 0.24829 & -1.06436 & 0.25878 \\
Leaf litter outside vegetation & -0.03897 & 0.695886 & 0.37279 \\
Grass (lenght) & -0.42875 & -0.63057 & -0.37408 \\
Tree (lenght) & 1.04806 & -0.19303 & -0.04763 \\
Tree (height) & 1.05482 & 0.009813 & 0.125 \\
Dried plants (lenght) & -0.81408 & 0.164299 & 0.45597 \\
Dried plants (height) & -0.60029 & -0.34643 & 0.18065 \\
Deep of leaf litter & 0.75715 & 0.178587 & 0.02028 \\
Grass (height) & 0.10124 & -0.71505 & -0.31302 \\
Bush (height) & 0.91355 & 0.022454 & 0.19917 \\
Bare sand & -0.01557 & 0.45236 & -0.98978 \\
\hline
\end{tabular}

and guriri (that were important to distinguish Jurubatiba from the other areas - Fig. 1, Table 2).

We did not find a significant relationship between the number of lizards sighted in each transect and the gradients captured by the first two axis of PCA (GLM, results: $Z=1.96 ; p=0.05 ; N=60$ and $Z=1.92 ; p=0.05 ; N=60$ ), although the $p$-value were near to significance.

\section{Sightings}

We recorded a total of 58 individuals of G. littoralis in Jurubatiba, with a range of 1 to 7 individuals among transects $(\bar{x}=2.9 \pm 1.5$ individual per transect; $N=20$ ). In Maricá, the encounter rate ranged from 0 to 8 individuals per transect $(\bar{x}=3.3 \pm 2.2 ; \mathrm{N}=20$ ) within a total of 67 individuals recorded. Grussai was the restinga with the lowest encounter rate among the three study sites -0 to 5 individuals ( $\bar{x}=1.7 \pm 1.8$ individuals/transect; $N=20$ ), with a total of 33 sightings.

The micro-habitat in which more individuals were seen was leaf litter on the edge of bush, with $37.6 \%$ of the records, followed by leaf litter inside bush (20.1\%), guriri (14.9\%) and bare sand ground cover (14.3\%). Cactus and herbaceous vegetation, in turn, were the micro-habitats in which there were fewer records of lizards, representing only $0.65 \%$ of sightings (Fig. 2).

Leaf litter on the edge of bushes was the micro-habitat with more records of G. littoralis in Maricá and Grussaí while guriri was the micro-habitat with greater amount of total sightings in Jurubatiba (Fig. 3). According to the Komolgorov-Smirnov test, there were differences in the use of micro-habitats by lizards among the three restingas: $\mathrm{D}=0.7143, \mathrm{p}=0.0015, \mathrm{~N}=7$ (between Maricá and Grussaí); $\mathrm{D}=0.8571, \mathrm{p}<0.0001, \mathrm{~N}=7$ (between Maricá and Jurubatiba) and $\mathrm{D}=0.7857, \mathrm{p}=0.00035, \mathrm{~N}=7$ (between Grussaí and Jurubatiba).

\section{Use of the habitat}

In Grussaí, occupancy of lizards was best explained by three more plausible models (Table 3 ), since there 
Table 3. Grussaí models with AIC value $<2$.

\begin{tabular}{lcccccc}
\hline \multicolumn{1}{c}{ Model } & AIC & AAIC & W AIC & Likelihood & № par. & -2 log like \\
\hline $\boldsymbol{\Psi}$ (bush_H) p(grass, time) & 81.16 & 0.00 & 0.4294 & 1.0000 & 7 & 67.16 \\
$\boldsymbol{\Psi}$ (bush_H) p(grass) & 81.96 & 0.80 & 0.2878 & 0.6703 & 4 & 73.96 \\
$\boldsymbol{\Psi}$ (bush_H, sand) p(grass, time) & 83.16 & 2.00 & 0.1580 & 0.3679 & 8 & 67.16 \\
\hline
\end{tabular}

was no significant difference between them. In terms of occupancy $(\Psi)$, we can infer that the height of bushes negatively affected the presence of local individuals, and bare sand, when analyzed together with height of shrubs, showed a positive influence on occupation. The detectability ( $p$ ) of lizards in Grussaí was influenced by two covariates, the length of grass and time (period of sampling) (Table 3 ). The probability of detecting the individuals varied over the four periods of observation (it was lower in the last) and was negatively affected
Table 4. Jurubatiba models with $\triangle$ AIC value $<2$; ' $\Psi$ ' means occupancy and ' $\mathrm{p}$ ' detectability.

\begin{tabular}{|c|c|c|c|c|c|c|}
\hline Model & AIC & $\triangle A I C$ & W AIC & Likelihood & № par. & $-2 \log$ like \\
\hline $\boldsymbol{\Psi}$ (.) p (time) & 110.56 & 0.00 & 0.2054 & 1.0000 & 5 & 100.56 \\
\hline $\boldsymbol{\Psi}()$.$p (time, guriri)$ & 100.69 & 0.13 & 0.1925 & 0.9371 & 6 & 98.69 \\
\hline$\Psi($ (.) p (time, d_plant) & 110.97 & 0.41 & 0.1674 & 0.8146 & 6 & 98.97 \\
\hline $\boldsymbol{\Psi}$ (.) p (time, bush_H) & 112.56 & 2.00 & 0.0756 & 0.3679 & 6 & 100.56 \\
\hline
\end{tabular}

by the length of grass in the three models presented (Table 3).

In Jurubatiba, we accepted four models for occupancy and detectability estimation (Table 4). The occupancy was not influenced by any characteristic of vegetation, and was constant in all models selected. The detection of $G$. littoralis was influenced, in this restinga, by time (having a positive relationship with the first period of

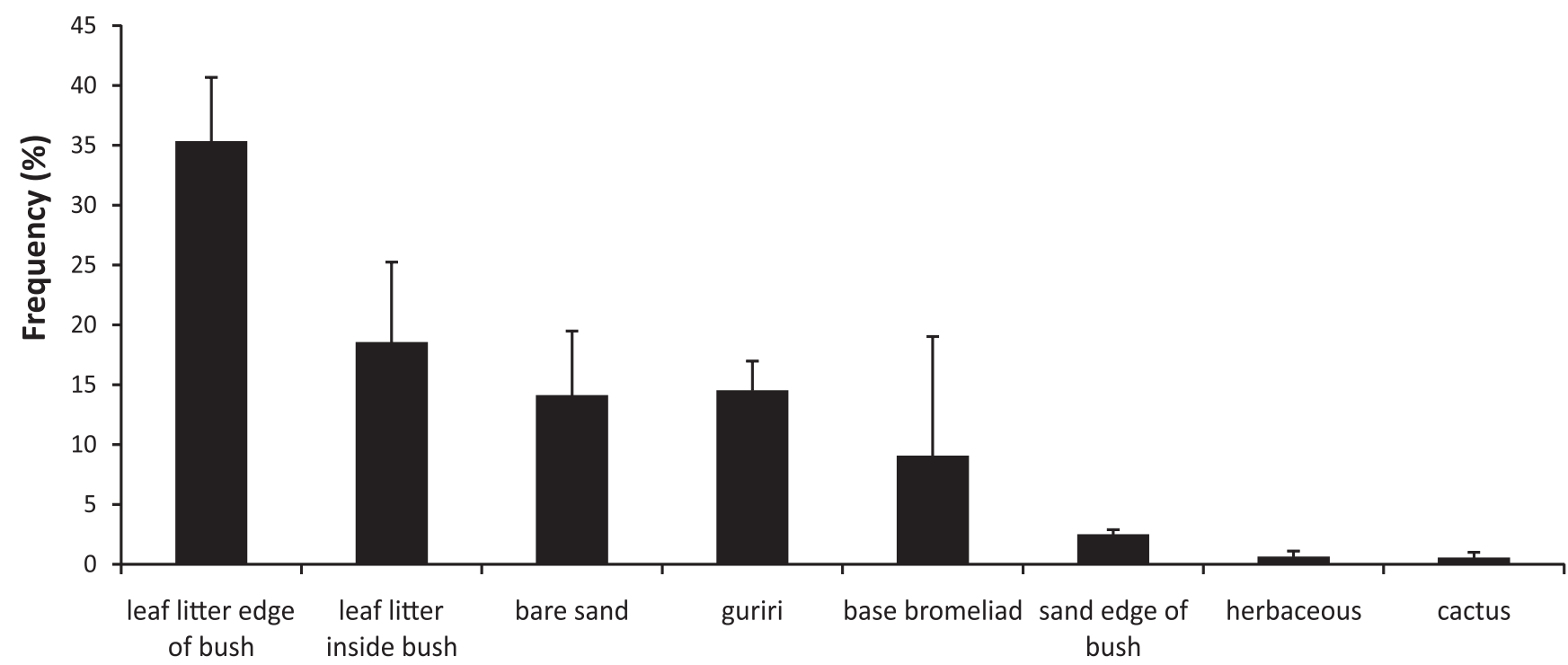

Figure 2. Percentage of individual sighted in micro-habitats available in the three restingas studied (pooled data).

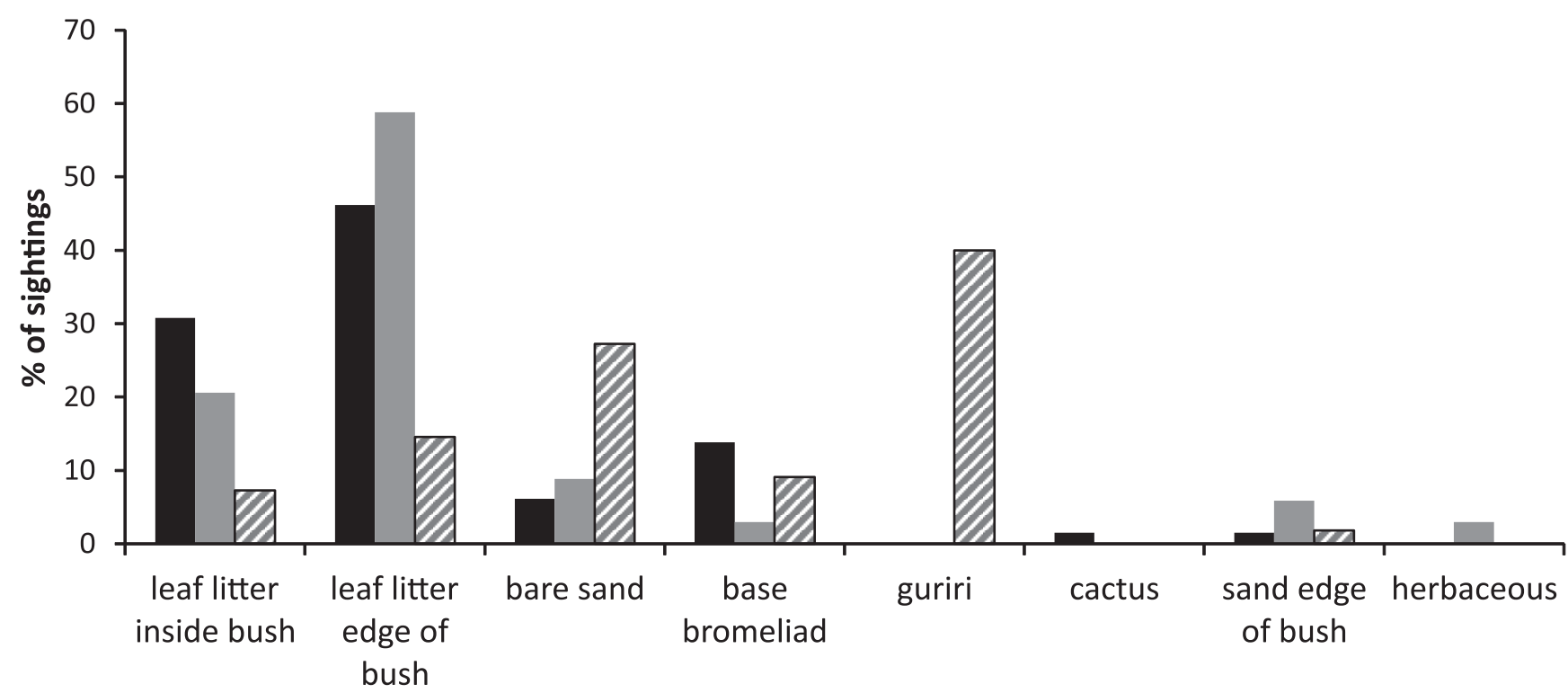

- Maricá - Grussaí घJurubatiba

Figure 3. Sightings frequency in each micro-habitat available in restingas separately. 
Table 5. Maricá models with $\triangle \mathrm{AIC}$ value $<2 ;{ }^{\prime} \Psi$ ' means occupancy and ' $\mathrm{p}$ ' detectability.

\begin{tabular}{|c|c|c|c|c|c|c|}
\hline Model & AIC & $\triangle \mathrm{AIC}$ & W AIC & Likelihood & № par. & $-2 \log$ like \\
\hline$\Psi()$.$p (bush_H)$ & 114.67 & 0.00 & 0.0965 & 1.0000 & 3 & 108.67 \\
\hline $\boldsymbol{\Psi}(.) \mathrm{p}$ (litter_D) & 114.85 & 0.18 & 0.0882 & 0.9139 & 3 & 108.85 \\
\hline$\Psi() p.()$. & 114.90 & 0.23 & 0.0861 & 0.8914 & 2 & 110.90 \\
\hline $\boldsymbol{\Psi}$ (.) p (bush_H, time) & 115.24 & 0.57 & 0.0726 & 0.7520 & 6 & 103.24 \\
\hline$\Psi$ (.) p (litter_D, time) & 115.44 & 0.77 & 0.0657 & 0.6805 & 6 & 103.44 \\
\hline $\boldsymbol{\Psi}$ (.) p (time) & 115.64 & 0.97 & 0.0594 & 0.6157 & 5 & 105.64 \\
\hline$\Psi$ (.) p (tree_H) & 116.55 & 1.88 & 0.0377 & 0.3906 & 3 & 110.55 \\
\hline$\Psi()$.$p (d_plant)$ & 116.61 & 1.94 & 0.0366 & 0.3791 & 3 & 110.61 \\
\hline$\Psi$ (cactus) p (.) & 116.66 & 1.99 & 0.0357 & 0.3697 & 3 & 110.66 \\
\hline $\boldsymbol{\Psi}$ (cactus) p (bush_H) & 116.67 & 2.00 & 0.0355 & 0.3679 & 4 & 108.67 \\
\hline
\end{tabular}

observation and more negative with the latest one), and by some structures of vegetation, as length of guriri and dried plants (positive relationship) and height of bushes (negative relation) (Table 4).

In Maricá, the presence of lizards was explained by 10 plausible models (Table 5). The occupancy was constant in the majority of the models selected, and was positively influenced only by the presence of cactus. The detectability was negatively influenced by height of bushes, depth of leaf litter and height of trees; and positively influenced by dried plants. The detectability of the individuals also changed with the period of observation; it was higher in the second (10h30-12h00) period and lower in the fourth (13h30-15h00). The first and third period showed some influence only in one model, having a positive and negative influence, respectively (Table 5).

\section{DISCUSSION}

We found differences in the structure of vegetation among the restingas. Although all the tree areas had a similar length of bare sand, which was the variable with the highest percentage of ground cover in all areas, in terms of vegetation however, our results showed particularities in each area (see appendix), being grass and guriri the structures that most distinguished among them. The vegetation structure of Grussaí stood out from the others, as previously proposed by Assumpção \& Nascimento (2000). It had the lowest coverage by bromeliads, which is a type of vegetation considered important in structuring plant communities of restingas (Oliveira et al., 1994; Rocha et al., 2004), and the highest percentage of leaf litter associated with vegetation. The large length of leaf litter is probably due to the huge coverage of bush in this area, which was higher than that found in the other two.

We also found differences concerning the use of micro-habitat by $G$. littoralis among the areas. Besides the variation in the frequency of utilization of the micro-habitats depending on the restingas, our models showed differences between the areas in terms of presence of individuals. The occupancy of individuals was affected by three kinds of micro-habitat: height of bushes, sand (Grussaí) and cactus (Maricá). The occupancy probability reveals which structures of vegetation influence the presence of lizards due the effects they have on the environment, and not necessarily that they are being directly used by individuals. Height of bushes had a negative influence possibly because tall bushes tend to increase shaded area (it should be noted that in this category we analyzed only bushes with leaves), reducing the amount of sun that reaches the ground. These micro-habitats may be out of the set point range temperature of G. littoralis, hindering the optimization of lizard thermoregulation and so reducing their occupancy by lizards. However, when the variable extent of bare sand was considered together with height of bushes as a covariate, it revealed a positive influence on the occupancy. The combination between bare sand and a gradient of height of bushes may create potential micro-habitats providing appropriate temperatures for thermoregulation during the hottest periods of the day. Cactus, otherwise, had a positive influence for Maricá population, probably because they are good sites for thermoregulation, mainly during the afternoon, to keep the heat and stay warm (Vrcibradic \& Rocha, 2002; Rocha et al., 2009). Although cactus strongly influenced the presence of lizard individuals, its effect was lower when analyzed together with the height of bushes. This probably occurred because tall bushes potentially reduce the visualization of individuals, affecting the detectability, as well as the exposure of the cactus superficies to solar radiation, making it difficult to get heat (Vrcibradic \& Rocha, 2002).

In terms of detectability, we found seven structural variables influencing the visualization of individuals: extent of grass, height of bush and trees, depth of leaf litter, extent of guriri, dried plants and the hour of the sampling. Probably the amount of grass may have a negative influence in detectability to, in some way, hide the individuals; height of trees, as well as height of bushes, had a negative influence probably because they increase the amount of shadow zones; depth of leaf litter negatively influenced detectability probably because lizards may remain less visible to observers, who are visually oriented, in thicker layers; while later periods of observation could have influence the detectability due to the higher amount of shadows occurring in this moment of the day. Dried plants, otherwise, positively affected detectability of lizards in Maricá, providing no shelter for them to hide.

Bushes were the vegetation structure that had most negative influence either in terms of occupancy or detectability in all restingas. Grussaí, for example, besides having the minor amount of bromeliad cover, was the restinga with the highest cover of bushes (see appendix) and the lowest number of transects with lizard detections. Since we found a near statistical significance between the physical structure of restingas and the number of lizards individuals sighted in it, we assumed that the vegetation structure of Grussaí can be one possible explanation for the small number of lizard individuals occurring in this area. This assumption goes according to previous studies that classified Grussaí as the restinga with the lowest density of $G$. littoralis (Menezes \& Rocha, 2013; Cosendey et al., 2016), adding the structure of vegetation as another possible explanation beyond the deg- 
radation (Cosendey et al., 2016) for the lower number of G. littoralis individuals in this area. Besides that, this was also the restinga with the highest amount of grass, which could have influenced the detectability of the individuals. The area with the highest concentration of grass was the nearest to the harbor area, where there were evidences of commercial quarrying of sand (Cosendey et al., 2016).

Different types of micro-habitats are used by lizards for different functions in restingas. Cactus provide sites for thermoregulation (Vrcibradic \& Rocha, 2002), while bromeliads provides shelter, preys and source of water (Oliveira \& Rocha, 1997). We recorded the highest number of $G$. littoralis on the leaf litter at the edge of bushes, a micro-habitat where this lizards' species has been reported to prefer (Hatano et al., 2001; Araujo et al., 1998), due to the heliothermic characteristic of this genus (Teixeira-Filho et al., 1995; Vitt, 1995) that favors open areas (Teixeira-Filho et al., 1995; Menezes et al., 2011) where they can forage and get the necessary sunlight for thermoregulation (Silva \& Araújo, 2008; Menezes et al., 2000). Leaf litter associated with any type of vegetation had a positive relationship with lizard abundance both in Grussaí and Jurubatiba. In other studies, bare sand (Hokit et al., 1999) and grass (Germano \& Lawhead, 1986) had a positive relation with the occupancy by others lizard species. Taking these specificities into account, the existence of a given structure in restingas makes them more suitable for $G$. littoralis individuals, as well as the loss of some key habitat structures would probably have negative effects in lizards' population's dynamics.

\section{CONCLUSION}

Our data showed that the physical structure of restingas had their particularities within the studied areas, affecting in different ways the detectability and local occupancy of $G$. littoralis as well as the use of micro-habitats. Once vegetation is fundamental to lizards due to their use as a refuge and site for thermoregulation, shelter and feeding, and the ecology of species make them sensible to changes in environmental characteristics (Pianka \& Vitt, 2003; Faria et al., 2007), understanding the effects of habitat loss (Cosendey et al., 2016), degradation and fragmentation of the habitat becomes essential to the development of public policies to conserve the fragmented ecosystems (Hokit et al., 1999). The endemism of G. littoralis to only four restingas areas of Rio de Janeiro State, the specificity in the use of micro-habitat, the requirement of specific body temperatures and the relatively low brood size (Menezes \& Rocha, 2014), can contribute to their vulnerability to structural changes in the habitat. Once the populations studied are restricted to isolated areas represented by fragments surrounded by large cities and deforested areas, individuals cannot migrate, which threatened them even more in terms of extinction risk. Thus, the protection of restinga vegetation and the creation of appropriate management plans (Hokit et al., 1999), as the strengthening of conservation units, is essential for the well-being of this species.

\section{ACKNOWLEDGMENTS}

This study is portion of the results of both the "Programa de Pesquisas em Biodiversidade do Estado do Rio de Janeiro - BIOTA Rio" supported by Fundação Carlos Chagas Filho de Amparo à Pesquisa do Estado do Rio de Janeiro - FAPERJ (Process No. E-26_010.001639_2014) to CFD Rocha and the "Programa de Pesquisas em Biodiversidade da Mata Atlântica (PPBio Mata Atlântica Program)" of Ministério do Meio Ambiente do Brasil (MMA) supported by Conselho Nacional de Desenvolvimento Científico e Tecnológico (CNPq) (Process No. 457458/212-7). We count with the support of Fundação Grupo Boticário de Proteção à Natureza (Project 1129_20182). The authors also benefitted from grants provided to CFDR (302974/2015-6 and 424473/20160) from CNPq and through "Cientistas do Nosso Estado" Program from FAPERJ (process No. E-26/202.920.2015 and E-26/202.803.2018). BNC received a doctoral fellowship (process: E-26/200.507/2016) from Fundação Carlos Chagas Filho de Amparo à Pesquisa do Estado do Rio de Janeiro (FAPERJ). VAM benefited by pos-doctoral fellowships from FAPERJ (100.005/2009), received a Visiting Professor Grant from UERJ and currently receives a PROTEC productivity fellowship from FAPERJ/UEZO (Process No. E-26/200.031/2019). We thank E. Gomes, T. Moulton, L. Fusinatto and V. Borges Jr. for kindly reviewing the manuscript, and the personnel of the the Reserva Particular do Patrimônio Natural Fazenda Caruara and Parque Nacional da Restinga de Jurubatiba for allowing access to those areas. We also thank Coordenação de Aperfeiçoamento de Pessoal de Nível Superior - CAPES, for funding part of the project.

\section{REFERENCES}

Anton, J.R.I.; Rotger, A.; Igual, J.M. \& Tavecchia, G. 2013. Estimating lizard population density: an empirical comparison between line-transect and capture-recapture methods. Wildlife Research, 40(7): 552-560.

Araujo, D.S.D.; Scarano, F.R.; Kurtz, B.C.; Zaluar, H.L.T.; Montezuma, R.C.M. \& Oliveira, R.C. 1998. Comunidades vegetais do Parque Nacional de Restinga de Jurubatiba. In: Esteves, F.A. (Ed.). Ecologia das lagoas costeiras do Parque Nacional da Restinga de Jurubatiba e do município de Macaé. Rio de Janeiro, NUPEM-UFRJ. p. 37-62.

Ariani, C.V.; Pickles, R.S.A.; Jordan, W.C.; Lobo-Hadju, G. \& Rocha, C.F.D. 2013. Mitochondrial DNA and microsatellite loci data supporting a management plan for a critically endangered lizard from Brazil. Conservation Genetics, 14(5): 943-951. D0I

Arnold, T.W. 2010. Uninformative Parameters and Model Selection Using Akaike's Information Criterion. Journal of Wildlife Management, 74(6): 1175-1178; 2010.

Assumpção, J. \& Nascimento, M.T. 2000. Estrutura e composição florística de quatro formações vegetais de restinga no complexo lagunar Grussaí/ Iquipari, São João da Barra, RJ, Brasil. Acta Botanica Brasilica, 14(3): 301-315.

Cerqueira, R.; Brant, A.; Nascimento, M.T. \& Pardini, R. 2003. Fragmentação: alguns conceitos. In: Rambaldi, D.M. \& Oliveira, D.A.S. Fragmentação de Ecossistemas - causas, efeitos sobre a biodiversidade e recomendações de políticas públicas. Brasília, MMA/SBF, 2003. 
Cesário, L.F. \& Gaglianone, M.C. 2008. Biologia floral e fenologia reprodutiva de Schinus terebinthifolius Raddi (Anacardiaceae) em Restinga do Norte Fluminense. Acta Botanica Brasilica, 22(3): 828-833.

Clobert, J.; Le Galliard, J.; Cote, J.; Meylan, S. \& Massot, M. 2009. Informed dispersal, heterogeneity in animal dispersal syndromes and the dynamics of spatially structured populations. Ecology Letters, 12: 197-209.

Cosendey, B.N.; Rocha, C.F.D. \& Menezes, V.A. 2016. Population density and conservation status of the teiid lizard Cnemidophorus littoralis, an endangered species endemic to the sandy coastal plains (restinga habitats) of Rio de Janeiro state, Brazil. Journal of Coastal Conservation, 20(2): 97-106. DOI

Decreto 41612 de 23 de dezembro de 2008. Dispõe sobre a definição de restingas no Estado do Rio de Janeiro e estabelece a tipologia e caracterização ambiental da vegetação de restinga. Rio de Janeiro, 2008.

Dias, E.J.R. \& Rocha, C.F.D. 2014. Habitat structural effect on Squamata fauna of the restinga ecosystem in Northeastern Brazil. Anais da Academia Brasileira de Ciências, 86(1): 359-371. DOI

Faria, D.; Paciência, M.L.B.; Dixo, M.; Laps, R.R. \& Baumgarten, J. 2007. Ferns, frogs, lizards, birds and bats in forest fragments and shade cacao plantations in two contrasting landscapes in the Atlantic forest, Brazil. Biodiversity and Conservation, 16: 2335-2357.

Franco, A.C.; Valerano, D.M.; Santos, F.M.; Hay, J.D.; Henriques, R.P.B. \& Medeiros, R.A. 1984. Os microclimas das zonas de vegetação da praia da Restinga de Barra de Maricá, RJ. In: Lacerda, L.D.; Araujo, D.S.D.; Cerqueira, R. \& Turq, B. (Orgs.). Restingas: origem, estrutura, processos. Niterói, CEUFF. p. 413-425.

Germano, D.J. \& Lawhead, D.N. 1986. Species diversity and habitat complexity: does vegetation organize vertebrate communities in the Great Basin? The Great Basin Naturalist, 46(4): 711-720.

Hatano, F.H.; Vrcibradic, D.; Galdino, C.A.B.; Cunha-Barros, M.; Rocha, C.F.D. \& Van Sluys, M. 2001. Thermal ecology and activity patterns of the lizard community of the restinga of Jurubatiba, Macaé, RJ. Revista Brasileira de Biologia, 61(2): 287-294. DOI

Hines, J.E. 2006. Presence - Software to estimate patch occupancy and related parameters. USGS-PWRC. Available at: www.mbr-pwr.usgs.gov/ software/presence.html.

Hokit, D.G.; Stith, B.M. \& Branch, L.C. 1999. Effects of landscape structure in Florida scrub: a population perspective. Ecological Applications, 9(1): 124-134.

Jackson, D.A. 1993. Stopping rules in principal components analysis: a comparison of heuristical and statistical approaches. Ecology, 74(8): 2204-2214.

Kohn, A.J. \& Leviten, P.J. 1976. Effect of Habitat Complexity on Population Density and Species Richness in Tropical Intertidal Predatory Gastropod Assemblages. Oecologia, 25: 199-210. DOI

MacKenzie, D.I. 2012. PRESENCE User Manual. 83p. Disponível em: www. clarkcountynv.gov/airquality/dcp/Documents/Library/dcp\%20 reports/2012/PRESENCE 0ccupancy Statistics\%20 Software Manual 20121112.pdf.

Maia-Carneiro, T.; Dorigo, T.A. \& Rocha, C.F.D. 2012. Influences of seasonality, thermal environment and wind intensity on the thermal ecology of Brazilian sand lizards in a restinga remnant. South American Journal of Herpetology, 7(3): 241-251. DOI

McCune, B. \& Mefford, M.J. 1999. PC-ORD. Multivariate Analysis of Ecological Data, version 5.0. Gleneden Beach, Oregon, MjM Software.

Menezes, V.A. \& Rocha, C.F.D. 2013. Geographic distribution, population densities, and issues on conservation of whiptail lizards in restinga habitats along the eastern coast of Brazil of whiptail lizards in restinga habitats along the eastern coast of Brazil. North-Western Journal of Zoology, 9(2): 337-344.
Menezes, V.A. \& Rocha, C.F.D. 2014. Clutch size in populations and species of cnemidophorines (Squamata: Teiidae) on the eastern coast of Brazil. Anais da Academia Brasileira de Ciências, Rio de Janeiro, 86(2): 707-722. D01

Menezes, V.A.; Amaral, V.C.; Sluys, M.V. \& Rocha, C.F.D. 2006. Diet and foraging of the endemic lizard Cnemidophorus littoralis (Squamata, Teiidae) in the restinga de jurubatiba, Macaé, RJ. Brazilian Journal of Biology, 66(3): 803-807. D01

Menezes, V.A.; Rocha, C.F.D. \& Dutra, G.F. 2000. Termorregulação no lagarto partenogenético (nemidophorus nativo (Teiidae) em uma área de restinga do nordeste do Brasil. Revista de Etologia, 2(2): 103-109.

Menezes, V.A.; Van Sluys, M.; Fontes, A.F. \& Rocha C.F.D. 2011. Living in a caatinga-rocky field transitional habitat: ecological aspects of the whiptail lizard Cnemidophorus ocellifer (Teiidae) in northeastern Brazil. Zoologia, 28(1): 8-16. D0I

Mingoti, S.A. 2013. In: Análise de dados através de métodos de estatística multivariada. Uma abordagem aplicada. Belo Horizonte, Editora UFMG. 297p.

Ministério do Meio Ambiente (MMA). 2014. Rio de Janeiro. Portaria № 444, de 17 de setembro de 2014. Lista oficial de espécies da fauna ameaçadas de extinção. Diário Oficial da União 245, 121-129, 17 sep. 2014. Section 1.

Montezuma, R.C.M. \& Araujo, D.S.D. 2007. Estrutura da vegetação de uma restinga arbustiva inundável no Parque Nacional da Restinga de Jurubatiba. Pesquisas Botânicas, São Leopoldo, RJ: Instituto Anchietano de Pesquisas 58: 157-176.

Nimer, E. 1972. Climatologia da região Sudeste do Brasil: introdução à climatologia dinâmica - subsídios à geografia regional do Brasil. Revista Brasileira de Geografia, Rio de Janeiro, 34(1): 3-48.

Oliveira, M.G.N. \& Rocha, C.D.F. 1997. 0 efeito da complexidade da broméliatanque Neoregelia cruenta (R. Graham) L.B. Smith sobre a comunidade animal associada. Revista Bromélia, 4(2): 13-22.

Oliveira, M.G.N.; Rocha, C.F.D. \& Bagnall, T. 1994. Bromélias-tanque servem de abrigo para espécies. Ciência Hoje, 17(97): 21-22.

Pereira, M.C.A.; Araujo, D.S.D. \& Pereira, 0.J. 2001. Estrutura de uma comunidade arbustiva da restinga de Barra de Maricá - RJ. Revista Brasileira de Botânica, 24(3): 273-28.

Pianka, E.R. \& Vitt, L.J. 2003. Lizards: windows to the evolution of diversity. Los Angeles, University of California Press. 333p.

Radder, R.S.; Saidapur, S.K. \& Shanbhag, A. 2005. Population density, microhábitat use and activity patter of the Indian rock lizard, Psammophilus dorsalis (Agamidae). Current Science, 89(3): 560-566.

Rocha, C.F.D. \& Bergallo, H.G. 1997. Intercommunity variation in the distribution of abundance of dominant lizard species in restinga habitats. Ciência e Cultura, 49(4): 269-274.

Rocha, C.F.D.; Bergallo, H.G.; Van Sluys, M.; Alves, M.A.S. \& Jamel, C.E. 2007. The remnants of restinga habitats in the brazilian Atlantic Forest of Rio de Janeiro state, Brazil: Habitat loss and risk of disappearance. Brazilian Journal of Biology, 67(2): 263-273. DOI

Rocha, C.F.D.; Hatano, F.H.; Vrcibradic, D. \& Van Sluys, M. 2008. Frog species richness, composition and $\beta$-diversity in coastal Brazilian restinga habitats. Brazilian Journal of Biology, 68(1): 101-107. DOI

Rocha, C.F.D.; Nunes-Freitas, A.F.; Cogliatti-Carvalho, L. \& Rocha-Pessôa, T.C. 2004. Habitat disturbance in the Brazilian coastal sand dune vegetation and related richness and diversity of bromeliad species. Vidalia, 2(2):49-55.

Rocha, C.F.D.; Van Sluys, M.; Bergallo, H.G. \& Alves, M.A.S. 2005. Endemic and threatened tetrapods in the Restingas of the biodiversity corridors of Serra do mar and of the Central da Mata Atlântica in eastern Brazil. Brazilian Journal of Biology, 65(1): 159-168. DOI

Rocha, C.F.D.; Van Sluys, M.; Vrcibradic, D.; Kiefer, M.C.; Menezes, V.A. \& Siqueira, C.C. 2009. Comportamento de termorregulação em lagartos brasileiros. Oecologia Brasiliensis, 13(1): 115-131. ISSN: 2177-6199. 
Rocha, C.F.D.; Vrcibradic, D.; Araújo, A.F.B.; Costa, E.M.; Teixeira-Filho, P. \& Menezes, V.A. 2001. Descoberto em restingas um novo réptil: lagartoda-cauda-verde. Ciência Hoje, 29(173): 86-87.

RStudio Team. 2012. RStudio: Integrated Development for R. RStudio, Boston, MA. Available at: www.rstudio.com.

Silva, V.N. \& Araújo, A.F.B. 2008. Ecologia dos lagartos brasileiros. Rio de Janeiro, Technical Books Editora, 271p.

Sinervo, B.; Méndez-de-la-Cruz, F.; Miles, D.B.; Heulin, B.; Bastiaans, E.; Villagrán-Santa Cruz, M.; Lara-Resendiz, R.; Martínez-Méndez, N.; Calderón-Espinosa, M.L.; Meza-Lázaro, R.N.; Gadsden, H.; Avila, L.J.; Morando, M.; De la Riva, I.J.; Sepulveda, P.V.; Rocha, C.F.D.; Ibargüengoytía; N.; Puntriano, C.A.; Massot, M.; Lepetz, V.; Oksanen, T.A.; Chapple, D.G.; Bauer, A.M.; Branch, W.R.; Clobert, J. \& Sites Jr., J.W. 2010.
Erosion of lizard diversity by climate change and altered thermal niches. Science, 328: 894-9. DOI

Teixeira-Filho, P.F.; Rocha, C.F.D. \& Ribas, S.C. 1995. Aspectos da ecologia termal e uso do hábitat por Cnemidophorus ocellifer (Sauria: Teiidae) na restinga da Barra de Maricá, RJ. Oecologia Brasiliensis, 1: 155-165. D0I

Vitt, L.J. 1995. The ecology of tropical lizards in the Caatinga of Northeast Brazil. Occasional Papers of the Oklahoma Museum of Natural History, 1: $1-29$.

Vrcibradic, D. \& Rocha, C.F.D. 2002. Use of Cacti as heat sources by thermoregulating Mabuya agilis (Raddi) and Mabuya macrorhyncha Hoge (Lacertilia, Scincidae) in two restinga habitats in southeastern Brazil. Revista Brasileira de Zoologia, 19: 77-83. D0I

\section{SUPPLEMENTARY MATERIAL - APPENDIX 1}

Table showing the type, measures (total length; minimum, maximum and average length \pm standard deviation; average height and percentage of coverage) and the number of times each extract of vegetation was recorded, including bare sand, in restingas of Barra de Maricá, Jurubatiba and Grussaí, in Rio de Janeiro State, Brazil.

\begin{tabular}{|c|c|c|c|c|c|}
\hline \multicolumn{3}{|c|}{ VEGETATION } & \multicolumn{3}{|c|}{ RESTINGAS } \\
\hline Category & Character & Measures & Maricá & Jurubatiba & Grussaí \\
\hline \multirow[t]{7}{*}{ Leaf Litter } & \multirow[t]{3}{*}{ Outside bush } & Total length (m) & 16.18 & 50.95 & 11.80 \\
\hline & & Average length (m) (min.-max.) & $0.32 \pm 0.26(0.04-1.23)(n=50)$ & $0.48 \pm 0.42(0.05-4.75)(n=105)$ & $0.24 \pm 0.18(0.03-0.71)(n=49)$ \\
\hline & & $\%$ of cover & 1.64 & 4.80 & 1.13 \\
\hline & \multirow[t]{3}{*}{ With vegetation } & Total length (m) & 75.69 & 144 & 299.42 \\
\hline & & Average length (m) (min.-max.) & $1.05 \pm 1.77(0.06-12.00)(n=72)$ & $1.00 \pm 0.92(0.09-6.30)(n=144)$ & $1.55 \pm 2.19(0.05-14.78)(n=193)$ \\
\hline & & $\%$ of cover & 7.69 & 13.57 & 28.80 \\
\hline & \multicolumn{2}{|l|}{ Average depth (m) } & $0.02 \pm 0.02(n=122)$ & $0.02 \pm 0.01(n=249)$ & $0.01 \pm 0.007(n=247)$ \\
\hline \multirow[t]{8}{*}{ Herbaceous } & \multirow[t]{4}{*}{ alive } & Total length (m) & 64.29 & 43.11 & 120.99 \\
\hline & & Average length (m) (min.-max.) & $0.35 \pm 0.67(0.005-6.50)(n=184)$ & $0.29 \pm 0.33(0.005-1.84)(n=149)$ & $0.53 \pm 1.55(0.005-13.91)(n=230)$ \\
\hline & & $\%$ of cover & 6.53 & 4.14 & 11.64 \\
\hline & & Average height (m) & $0.15 \pm 0.17(n=184)$ & $0.15 \pm 0.11(n=149)$ & $0.08 \pm 0.11(n=230)$ \\
\hline & \multirow[t]{4}{*}{ dried } & Total length $(\mathrm{m})$ & 0.01 & 0.68 & 25.09 \\
\hline & & Average length (m) (min.-max.) & $-(n=1)$ & $0.23 \pm 0.006(0.00-0.23)(n=3)$ & $0.33 \pm 0.76(0.00-6.50)(n=76)$ \\
\hline & & $\%$ of cover & 0.001 & 0.064 & 2.41 \\
\hline & & Average height (m) & $0.16(n=1)$ & $0.12 \pm 0.07(n=3)$ & $0.043 \pm 0.04(n=76)$ \\
\hline Bare sand & Outside bush & $\begin{array}{c}\text { Total length (m) } \\
\text { Average length (m) (min.-max.) } \\
\% \text { of cover }\end{array}$ & $\begin{array}{c}470.45 \\
1.39 \pm 1.9(0.17-17.9)(n=337) \\
47.82\end{array}$ & $\begin{array}{c}472.9 \\
1.15 \pm 1.25(0.02-9.04)(n=411) \\
44.55\end{array}$ & $\begin{array}{c}413.11 \\
0.88 \pm 1.46(0.01-13.91)(n=471) \\
39.75 \\
\end{array}$ \\
\hline \multirow[t]{8}{*}{ Cactus } & \multirow[t]{4}{*}{ alive } & Total length (m) & 4.08 & 17.62 & 43.72 \\
\hline & & Average length (m) (min.-max.) & $0.27 \pm 0.20(0.00-0.55)(n=15)$ & $0.25 \pm 0.26(0.01-3.8)(n=70)$ & $0.48 \pm 0.69(0.00-2.9)(n=90)$ \\
\hline & & $\%$ of cover & 0.41 & 1.60 & 4.20 \\
\hline & & Average height (m) & $0.77 \pm 0.67(n=15)$ & $0.44 \pm 0.34(n=70)$ & $0.38 \pm 0.31(n=90)$ \\
\hline & \multirow[t]{4}{*}{ dried } & Total length (m) & 0.75 & 0.28 & 3.55 \\
\hline & & Average length (m) (min.-max.) & $0.37 \pm 0.26(0.00-1.50)(n=2)$ & $0.14 \pm 0.13(0.00-0.23)(n=2)$ & $0.24 \pm 0.28(0.00-0.85)(n=15)$ \\
\hline & & $\%$ of cover & 0.08 & 0.026 & 0.34 \\
\hline & & Average height (m) & $0.79 \pm 0.99(n=2)$ & $0.05 \pm 0.02(n=2)$ & $0.17 \pm 0.13(n=15)$ \\
\hline \multirow[t]{8}{*}{ Bromeliad } & \multirow[t]{4}{*}{ alive } & Total length (m) & 152.77 & 73.32 & 57.08 \\
\hline & & Average length (m) (min.-max.) & $1.17 \pm 1.59(0.14-12.10)(n=131)$ & $0.67 \pm 0.79(0.00-2.51)(n=110)$ & $1.36 \pm 2.20(0.00-13.00)(n=42)$ \\
\hline & & $\%$ of cover & 15.53 & 6.90 & 5.49 \\
\hline & & Average height (m) & $0.60 \pm 0.62(n=131)$ & $0.49 \pm 0.19(n=110)$ & $0.61 \pm 0.21(n=42)$ \\
\hline & \multirow[t]{4}{*}{ dried } & Total length (m) & 1.89 & 0.38 & 4.38 \\
\hline & & Average length (m) (min.-max.) & $0.31 \pm 0.11(0.00-0.51)(n=6)$ & $0.19 \pm 0.09(0.12-0.26)(n=2)$ & $0.29 \pm 0.23(0.00-0.90)(n=15)$ \\
\hline & & $\%$ of cover & 0.1921 & 0.036 & 0.42 \\
\hline & & Average height (m) & $0.2 \pm 0.13(n=6)$ & $0.26 \pm 0.9(n=2)$ & $0.35 \pm 0.19(n=15)$ \\
\hline
\end{tabular}


Table showing the type, measures (total length; minimum, maximum and average length \pm standard deviation; average height and percentage of coverage) and the number of times each extract of vegetation was recorded, including bare sand, in restingas of Barra de Maricá, Jurubatiba and Grussaí, in Rio de Janeiro State, Brazil.

\begin{tabular}{|c|c|c|c|c|c|}
\hline \multicolumn{3}{|c|}{ VEGETATION } & \multicolumn{3}{|c|}{ RESTINGAS } \\
\hline Category & Character & Measures & Maricá & Jurubatiba & Grussaí \\
\hline \multirow{12}{*}{$\begin{array}{l}\text { Guriri } \\
\text { (Allagoptera sp.) }\end{array}$} & \multirow[t]{4}{*}{ adult } & Total length (m) & 4.93 & 159.40 & 96.14 \\
\hline & & Average length (m) (min.-max.) & $0.99 \pm 0.39(0.00-1.41)(n=5)$ & $0.82 \pm 0.57(0.08-3.60)(n=193)$ & $1.46 \pm 1.05(0.00-5.59)(n=66)$ \\
\hline & & $\%$ of cover & 0.5 & 14.94 & 9.25 \\
\hline & & Average height (m) & $1.078 \pm 0.18(n=5)$ & $0.56 \pm 0.32(n=193)$ & $0.95 \pm 0.59(n=66)$ \\
\hline & \multirow[t]{4}{*}{ dried } & Total length $(\mathrm{m})$ & - & 66.12 & 21.03 \\
\hline & & Average length $(\mathrm{m})$ (min.-max.) & - & $0.46 \pm 0.38(0.00-2.26)(n=144)$ & $0.40 \pm 0.27(0.06-1.25)(n=52)$ \\
\hline & & $\%$ of cover & - & 6.23 & 2.02 \\
\hline & & Average height (m) & - & $0.08 \pm 0.27(n=144)$ & $0.14 \pm 0.17(n=52)$ \\
\hline & \multirow[t]{4}{*}{ seedling } & Total length (m) & - & 0.82 & 0.67 \\
\hline & & Average length (m) (min.-max.) & - & $0.20 \pm 0.17(0.00-0.44)(n=4)$ & $0.17 \pm 0.12(0.00-0.34)(n=4)$ \\
\hline & & $\%$ of cover & - & 0.08 & 0.06 \\
\hline & & Average height (m) & - & $0.14 \pm 0.07(n=4)$ & $0.16 \pm 0.11(n=4)$ \\
\hline \multirow[t]{4}{*}{ Tree } & & Total length (m) & 47.77 & 5.96 & 1.06 \\
\hline & & Average length (m) (min.-max.) & $1.65 \pm 0.99(0.00-4.40)(n=29)$ & $1.19 \pm 0.83(0.00-2.25)(n=5)$ & $--(n=1)$ \\
\hline & & $\%$ of cover & 4.85 & 0.56 & 0.10 \\
\hline & & Average height (m) & $2.58 \pm 0.88(n=29)$ & $2.61 \pm 0.81(n=5)$ & $1.71(n=1)^{*}$ dried \\
\hline \multirow[t]{8}{*}{ Bush } & \multirow[t]{4}{*}{ alive } & Total length (m) & 195.15 & 130.54 & 358.02 \\
\hline & & Average length (m) (min.-max.) & $2.12 \pm 2.59(0.10-12.10)(n=92)$ & $1.19 \pm 1.08(0.00-5.60)(n=109)$ & $1.56 \pm 1.85(0.09-13.00)(n=229)$ \\
\hline & & $\%$ of cover & 19.83 & 12.02 & 34.44 \\
\hline & & Average height (m) & $1.18 \pm 0.81(n=92)$ & $0.84 \pm 0.46(n=109)$ & $0.5 \pm 0.38(n=229)$ \\
\hline & \multirow[t]{4}{*}{ dried } & Total length (m) & 2.75 & 3.14 & 3.50 \\
\hline & & Average length (m) (min.-max.) & $0.92 \pm 0.48(0.00-1.36)(n=3)$ & $1.05 \pm 0.31(0.00-1.40)(n=3)$ & $0.87 \pm 0.57(0.21-1.58)(n=4)$ \\
\hline & & $\%$ of cover & 0.28 & 0.29 & 0.34 \\
\hline & & Average height $(\mathrm{m})$ & $0.42 \pm 0.52(n=3)$ & $1.04 \pm 0.63(n=3)$ & $0.64 \pm 0.6(n=4)$ \\
\hline \multirow[t]{8}{*}{ Grass } & alive & Total length $(\mathrm{m})$ & 15.01 & - & 34.05 \\
\hline & & Average length (m) (min.-max.) & $0.30 \pm 0.37(0.03-2.30)(n=50)$ & - & $0.37 \pm 1.0(0.00-6.5)(n=92)$ \\
\hline & & $\%$ of cover & 1.52 & - & 3.28 \\
\hline & & Average height (m) & $0.12 \pm 0.15(n=50)$ & - & $0.15 \pm 0.08(n=92)$ \\
\hline & dried & Total length $(\mathrm{m})$ & 2.59 & - & 9.72 \\
\hline & & Average length (m) (min.-max.) & $0.21 \pm 0.16(0.00-0.64)(n=12)$ & - & $0.25 \pm 0.3(0.01-1.37)(n=38)$ \\
\hline & & $\%$ of cover & 0.26 & - & 0.93 \\
\hline & & Average height $(\mathrm{m})$ & $0.09 \pm 0.14(n=12)$ & 一 & $0.05 \pm 0.04(n=38)$ \\
\hline \multicolumn{3}{|c|}{ Total measure per restinga (m) } & 983.84 & 1061.37 & 1039.37 \\
\hline
\end{tabular}

